\title{
Troels Nørager
}

Taking Leave of Abraham. An Essay on Religion and Democracy. Århus: Aarhus University Press 2008. 258 s. Kr. 298.

Troels Nørager forfølger i sin bog to mål: det ene er at detronisere Abraham som en "troens ridder". Det sker i form af en eksegese af Kierkegaards Frygt og Beven. Abraham, som ifølge Genesis 22 var parat til at ofre sin søn, Isak, til Gud, repræsenterer en form for autoritær religion, der ikke længere kan have gyldighed i en moderne eller for den sags skyld postmoderne verden. Det andet er at argumentere for, at i et demokratisk samfund har religionen eller religiøse mennesker ret til at ytre sig i debatten på lige fod med ateister og alle mulige andre - når man altså én gang for alle har sagt farvel til Abraham. At Kierkegaard i Frygt og Baven sætter religionen over demokratiet/ etikken er jo ikke ligefrem en nyhed. Og tilmed er Nøragers eksegese lidt besværlig at læse, fordi han benytter ægtefællerne Hongs amerikanske oversættelse af bogen, som han så alligevel gentagne gange hen ad vejen må korrigere. Efter en diskussion og præsentation af den nyeste debat om sekulariseringen og den såkaldte "religionens genkomst", som Nørager fornuftigvis ikke giver meget for, kommer der mere substans ind $\mathrm{i}$ bogen, når han med tilslutning præsenterer først amerikaneren John Rawls’ (død 2002) og dernæst Jürgen Habermas' synspunkter på religionens plads i det moderne demokratiske samfund. Begge de to filosoffer er (eller var) enige om, at trods al sekularisering frem til i dag spiller religionen stadig en rolle. Og i et demokratisk samfund må troende eller religiøse mennesker derfor også have ret til at ytre sig med religiøse argumenter - i den forbindelse tager Nørager afstand fra den tidligere statsministers forsøg på at indskrænke religionen til den private sfære. Ifølge Rawls' “proviso” gælder denne ret dog kun, så længe vi (dvs. troende eller religiøse mennesker) er parate til at give "ægte offentlige grunde" for vores principper og politikker. Habermas' position er ikke meget anderledes. Også han, der tidligere har talt og skrevet om, at "det sakrale er blevet sprogliggjort”, og at der kun er få områder tilbage, hvor den religiøse trøst ikke kan oversættes til filosofisk eller politisk sprog - også han er nu parat til at lade religiøse argumenter indgå i den offentlige debat. Af grunde, som ikke er ganske indlysende for undertegnede anmelder, foretrækker Nørager i denne sammenhæng Rawls frem for Habermas. Med mindre det skyldes, men det kommer i så fald ikke klart frem, at Habermas tilsyneladende nu lader det, han tidligere kaldte "oversættelsesforbeholdet", hvile på den politiske debats ikke-religiøse deltagere.

Nøragers bog synes rettet mod et amerikansk læse-publikum. Ikke bare fordi den er skrevet på engelsk-amerikansk, men fordi den med en enkelt undtagelse eller to kun refererer til den engelsk-amerikanske debat om Kierkegaards, Rawls' og Habermas' synspunkter. Men den er så samtidig et skarpsindigt, vidende og væsentligt "forsøg" på at diskutere religionens rolle i det moderne, demokratiske samfund, som fortjener opmærksomhed både 
herhjemme og i det store udland, selv om jeg her kun har kunnet fremdrage enkelte hovedpunkter.

Men tillad mig så til slut at give udtryk for en stille undren: på samme forlag, i samme år, har to kolleger ved den samme institution (Det Teologiske Fakultet v. Aarhus Universitet) Vagn Andersen og Troels Nørager, begge religionsfilosoffer, udgivet hver sin bog, som begge et langt stykke hen ad vejen "cover the same ground" (Kierkegaard og Habermas). Men ingen af dem synes at have taget notits af den anden. Den ene af dem (Nørager) strejfer et par gange - ikke mindst i det afsluttende kapitel, hvor den ellers nærmest glemte russiske tænker Berdyaev drages ind - distinktionen mellem at være "menneske" og være samfundsborger (citizen). Og den anden (Andersen) fremhæver i sin Transformationen Gottes Kierkegaards subjektivitetstænkning vis-á-vis Habermas. Man skulle ellers tro, at her kunne den ene have haft noget at tale med den anden om!

Jens Glebe-Møller

\section{Nigel Biggar og Linda Hogan}

Religious Voices in Public Spaces. Oxford: Oxford University Press 2009. 334 s. $£ 62$.

De seneste 20 - 30 år har diskussionen om forholdet mellem religion og politik eller forholdet mellem teologisk etik og det liberale demokrati, eller hvordan man nu vil betegne feltet, indtaget en central plads og efterhånden antaget et omfang, så man må betegne det som et nyere, klassisk felt for den teologiske etik. Diskussionsfeltet er domineret af navne som John Rawls, Jürgen Habermas, Jeffrey Stout og Stanley Hauerwas. Det er indenfor dette felt at denne nye antologi tilsigter at yde et bidrag.

Sigtet med denne antologi er at gå ind $i$ en kritisk diskussion af den opfattelse af forholdet mellem religion og det offentlige rum, som Rawls har givet anledning til. Antologiens forskellige bidrag samler sig om den overordnede fælles opfattelse, at religion ikke kan henvises til det private rum. Det er særligt den rawlsianske tanke om, at omfattende livsanskuelser (comprehensive doctrines) - inkl. religiøse - systematisk må reserveres til enten den private sfære eller civilsamfundets baggrundskultur, som bidragene forholder sig kritisk til. Overfor den rawlsianske tanke om offentlig fornuft (public reason) samler bidragene sig om den opfattelse, at vejen til en stabil politisk kultur udgøres af et systematisk og seriøst engagement mellem forskellige og til tider modsatte livanskuelser.

Bogen er inddelt i tre hoveddele. I den første del giver bidragene en filosofisk begrundelse for en øget inklusion af religion i det offentlige ru. Anden del fokuserer på en teologisk begrundelse, hvor den sidste del diskuterer udvalgte konkrete spørgsmål. I kraft af sin karakter som antologi, argumenteres der $\mathrm{i}$ bogen på forskellig vis for dens overordnede antagelse. Et af de samlende argumenter, som ikke mindst findes hos Nicholas Wolterstorff, er, at 